\title{
The natural gas industry and its regulation in Latin America
}

\section{Humberto Campodónico}

ECLAC Consultant;

Principal Researcher,

Centre for Development

Studies and Promotion

(DESCO),

Lima, Peru, and

Director of the

Postgraduate Studies Unit,

Faculty of Economics,

Universidad Mayor de

San Marcos, Lima.
This article analyses the systems of regulation of the natural gas market in Argentina, Bolivia, Chile, Colombia and Mexico, which are the Latin American countries that have made most progress in this field, and it also presents some information on countries which had not yet defined their regulatory systems at the time of writing, such as Peru and Venezuela. First of all, it describes the situation of the natural gas industry worldwide and defines Latin America's place in it. It then studies the changes that have taken place in natural gas regulation systems in the region in the 1990s, especially with regard to the treatment given to exploration and production, and industrial processing, transport and marketing. The main features of the natural gas markets in the countries studied are then described, as well as the systems adopted for restructuring the industry, with special emphasis on the role of natural gas in regional energy integration. Finally, the article analyses the main features of natural gas regulation and the principles underlying it; the structure and powers of the regulatory bodies; the mechanisms for fixing the prices of extraction, transport and distribution; the different forms of subsidies, and the tax regime. 


\section{I}

\section{The behaviour of natural gas demand and world consumption projections}

Over the last twenty years, world demand for natural gas has grown faster than the demand for the other fossil fuels (oil and coal). In the period from 1971 to 1991, the demand for gas grew by $3.3 \%$ per year compared with $2.1 \%$ for coal and $1.4 \%$ for oil. ${ }^{1}$

This faster growth of natural gas consumption is due mainly to the following factors:

- Thanks to the abundant reserves of natural gas, its supply can be maintained for many years, and moreover these reserves are not very concentrated geographically (in contrast, nearly two-thirds of world oil reserves are in the Middle East).

- Technological advances have reduced the cost of transporting gas from the areas of production to the centres of consumption. ${ }^{2}$

- In recent decades greater importance has come to be attached to conservation of the environment, which favours the use of natural gas because it emits less carbon dioxide than oil.

- The growth of the energy markets of the emerging economies has made investments more attractive for both international and domestic operators.

$\square$ This article is based on a publication on this subject which appeared in the "Medio Ambiente y Desarrollo" series (No. 9) of the ECLAC Environment and Development Division.

${ }^{1}$ For detailed analyses, see United States Department of Energy, 1995, and OECD, International Energy Agency, 1995.

2 The transport of natural gas is more complicated than that of oil and coal, which are extracted in liquid and solid form, respectively, because it has to be kept in a completely sealed unit for transport and handling. Gas pipelines are the most common forms of transport, but when the distances are very great their use is not only difficult but also very costly. In that event, gas must be converted into liquid form at very low temperatures (liquefied natural gas) for transport in refrigerated ships to the markets, where it is subsequently "re-gasified" for distribution by gas pipelines. The problem with liquefied natural gas is that the conversion process and the cost of the ships, handling and special installations considerably increase its cost, thus making it less attractive economically (United States Department of Energy, 1995).
- The energy security policy of the OECD countries aims to reduce dependence on imported oil and natural gas, especially from the Middle East.

Most of world consumption of natural gas is concentrated in the OECD countries and in the former Soviet Union and the transitional economies of Eastern Europe, which account for $48 \%$ and $36 \%$ of world demand, respectively. Among the developing regions, the Middle East and Latin America each cover around 5\% of world demand, followed by East Asia and South Asia with $2.1 \%$ and $1.4 \%$ respectively. Africa covers $1.45 \%$ of world consumption and the People's Republic of China $0.75 \%$.

In the mid-1990s, oil, coal and natural gas -all fossil fuels- covered $91 \%$ of world energy consumption (oil, 38.8\%; coal, 28.4\% and natural gas, $23.6 \%$ ). Projections of energy consumption for the period from 1995 to 2020 indicate that this pattern is likely to continue (OECD, International Energy Agency, 1995). Demand for natural gas will continue to grow faster $(2.4 \%)$ than demand for coal $(2.1 \%)$ and oil $(0.8 \%)$. The proportion of total energy consumption covered by these three sources will thus increase to $92.2 \%$, due above all to the increase in natural gas consumption, whose share will increase to $25.2 \%$ while those of coal and oil will remain more or less unchanged (figure 1).

According to the OECD (1995), the developing countries will register the highest growth rate of consumption $(5.6 \%)$, followed by the OECD countries $(2.1 \%)$ and the former Soviet Union and transitional economies of Eastern Europe $(0.8 \%)$. China and the Middle East will have the highest growth rates for individual countries or regions $(8 \%$ and $7 \%$, respectively), while the projected growth rate for Latin America is 3\%, although other sources estimate it at $5 \% 3$ (OECD, International Energy Agency, 1995).

\footnotetext{
${ }^{3}$ There are discrepancies regarding the growth rate of demand for natural gas in Latin America. DRI-McGraw-Hill forecasts a growth rate of $5.1 \%$ per year in the region's demand during the period 1995-2015, which coincides with the projections of Amoco International (Oil \& Gas Journal, various issues).
} 
FIGURE 1

World energy consumption in 1995 and projections to the year 2020 (Percentages)

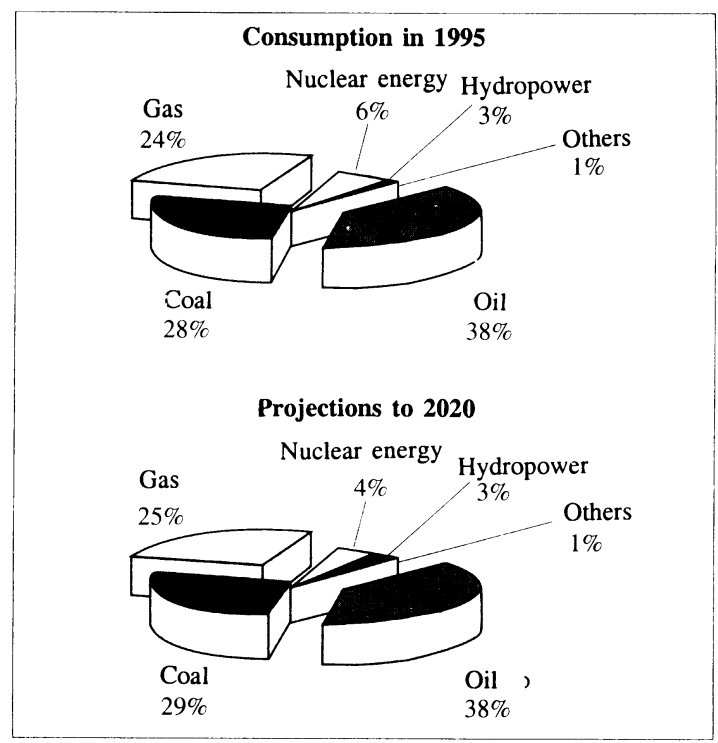

Source: OECD, International Energy Agency, 1995.

Such high rates will be reflected in the coming century in major changes in the structure of world demand for natural gas. The OECD countries will continue to be the main consumer market, but their share of the world total will go down from $48 \%$ to $45 \%$. The former USSR and the transitional economies of Eastern Europe will register a sharp drop of $10 \%$, thus accounting for $27 \%$ of the total, while the share of the developing countries in total world consumption will rise by $12 \%$ (to $27.8 \%$ of the total).

The reserves of the countries of the region have increased fourfold over the last 25 years (figure 2). Venezuela, Mexico and Argentina account for $89 \%$ of the total; Venezuela has over half the region's reserves (3962 × $10^{9}$ cubic metres). Brazil, Colombia, Ecuador and Peru have increased their reserves, but to a considerably smaller extent.

Few countries of the region are traditional natural gas producers: such production is usually linked with that of petroleum, and the pattern of natural gas production by countries is similar to that of their oil reserves, with Venezuela, Mexico and Argentina accounting for $84 \%$ of total regional natural gas production (figure 3).
FIGURE 2

Proven natural gas reserves in Latin America

(Billions of cubic metres)

FIGURE 2

Proven natural gas reserves in Latin America (Billions of cubic metres)

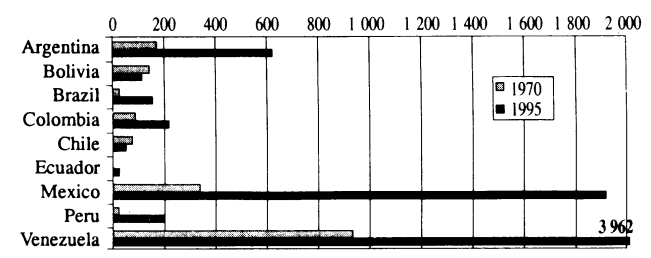

Source: OLADE, 1997a.

FIGURE 3

Natural gas production in Latin America

(Millions of cubic metres)

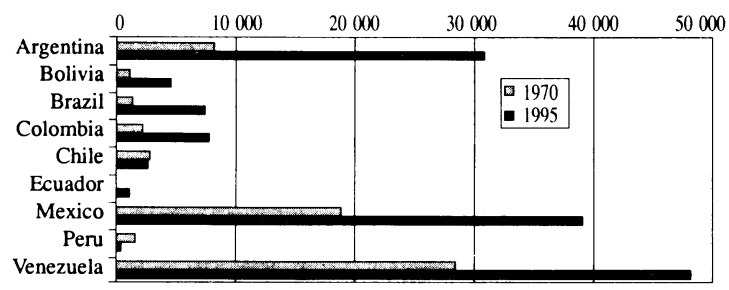

Source: OLADE, 1997a.

FIGURE 4

As regards the final energy demand of the countries of the region, $42 \%$ of this is covered by oil and $21 \%$ by electricity (hydro-electric, nuclear and geothermal plants). The share of natural gas is $18 \%$, compared with $15 \%$ for biomass and $4 \%$ for coal. However, this global figure fails to reflect the great disparities which exist in the region, since Argentina, Brazil and Venezuela account for $92 \%$ of regional demand (figure 4).

There continues to be a marked difference between the final demand for natural gas and its consumption for intermediate purposes. In 1995, the structure of the total supply of natural gas (final consumption plus intermediate consumption) by sectors in Latin America (table 1) showed that only $33 \%$ of natural gas went for final energy consumption (42,330 million cubic metres), mainly in the industrial sector (22\%), residential and other uses (5.9\%), and to a lesser extent in the commercial, non-energy and transport sectors. 
Natural gas consumption in Latin America

(Millions of cubic metres)

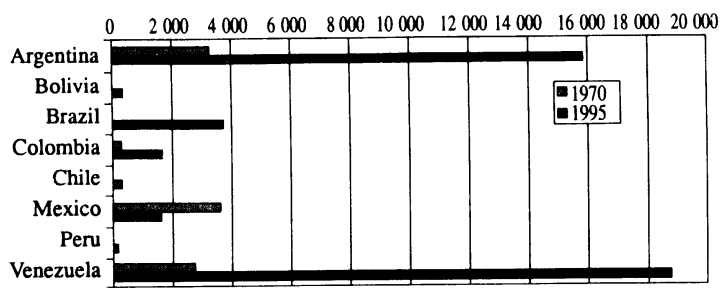

Source: OLADE, 1997a.

The other two-thirds of the total supply of 141,025 million cubic metres went for intermediate uses, such as gas treatment plants for the production of liquefied petroleum gas and gasoline (32.8\%), consumption by the natural gas companies themselves $(17.1 \%)$, and thermal and private power stations $(15.8 \%)$, the remainder being consumed by refineries, other uses, and losses.
TABLE 1

Latin America, 1996: Supply of gas, by use

(Percentages)

\begin{tabular}{lr} 
Gas treatment plants & 32.8 \\
Industry & 22.0 \\
Own consumption & 17.1 \\
Power plants & 13.2 \\
Residential and other & 5.9 \\
Non-energy uses & 2.9 \\
Private producers & 2.6 \\
Commercial & 1.4 \\
Transport & 0.8 \\
Other centres & 0.8 \\
Refineries & 0.5 \\
& \\
Total & 100.0 \\
Total, in millions of cubic metres & 141025 \\
\hline
\end{tabular}

Source: Kurtz, 1997.

Everything indicates, however, that final demand for natural gas will tend to grow in the coming years, in view of the major energy projects scheduled and some government policies which are promoting its consumption on a more generalized scale.

\section{II}

\section{Reforms in the natural gas industry}

In the course of the 1990s, most of the countries studied have made substantial reforms in their legislation governing the prospecting and exploitation of hydrocarbons (Argentina, Bolivia, Colombia, Chile). These reforms affect both petroleum and natural gas, since the prospecting and exploitation of these resources are similar, but they take account of the special features of natural gas. ${ }^{4}$

In Mexico, the oil industry legislation proper was not reformed, but substantial changes were made in the rules on the transport, storage and distribution of natural gas and the State enterprise Petróleos Mexicanos (PEMEX) retained its monopoly of natural gas prospecting and exploitation.

The origin and motives of the reforms which have been made in most of the countries of the region are to be found in the globalization process of the world economy, which favours the liberalization

${ }^{4}$ For a more detailed analysis of the hydrocarbons sector in ten countries of the region, see Campodónico, 1996. of markets, the elimination of State monopolies, the promotion of private investment and the reduction of State entrepreneurial activities. Substantial differences may be observed in the manner of application of these reforms, however, due to the influence of such factors as the amount of reserves and the production/consumption ratio for petroleum products and natural gas, the size of the domestic market, and the technological level and experience of the countries' oil and natural gas industries.

\section{Reforms in the rules on prospecting and exploitation of oil and natural gas}

The rules on prospecting and exploitation apply to both oil and natural gas. Generally speaking, the differences are in the amounts of royalties and the mechanisms for determining the sale price of first-hand natural gas, since natural gas does not have the same characteristics of an internationally tradeable good as oil. 
Almost all the countries studied in this article -except for Mexico, which has maintained the State monopoly of PEMEX- have reformed their systems of contracts for the prospecting and exploitation of crude oil and natural gas in order to attract venture capital so as to expand their available reserves and increase exports or reduce imports with a view to obtaining a more favourable net foreign exchange balance in their energy transactions.

Most of the countries analysed consider that greater investment incentives are needed in the light of the strong competition to attract venture capital in the current conditions of an over-supply of crude, low international oil prices, technological innovations which permit greater advantage to be taken of the existing reserves, and the elimination of barriers to foreign investment in some areas with major oil production potential (Russia, China).

Basically, the reforms have involved a reduction in tax rates on private operators and have affected the free commercial availability of the crude and natural gas extracted; there is also a tendency to do away with public monopolies in the sphere of extraction. In Argentina, Bolivia, Chile, Colombia and Peru, where there were no restrictions on foreign investment, the incentives have been concentrated on the following aspects:

- More flexible conditions with regard to technical aspects of the contracts: longer periods for prospecting, elimination of the obligation to drill test wells, longer periods of retention of areas under exploration, etc.

- Bigger shares in the amount of oil and natural gas produced or transfer of ownership of the oil and natural gas to the private operators themselves.

- Free import and export of oil and, in some cases, elimination of the obligation to keep the domestic market supplied.

- Greater profitability of the contracts because of the reduction in tax rates on income and remittances (in some cases tax on remittances was eliminated altogether); temporary duty-free importation of ma- chinery; accelerated depreciation, and other measures involving exemption or reduction of taxes.

- Greater guarantees for foreign investment through tax stability contracts, guaranteed availability of foreign exchange, possibility of resorting to international arbitration, etc.

\section{Reforms in industrial processing, transport and marketing}

In all the countries studied, changes have been made in the legislation governing the transport, distribution and marketing of natural gas. The reforms are designed to do away with barriers to private investment in an activity which, in many countries, was previously reserved for State enterprises. The deregulation of domestic markets has been promoted (elimination of subsidies and price controls) and free trading of oil and natural gas has been permitted on both the domestic and external markets.

The wellhead prices of natural gas for the domestic market have tended to be fixed generally in line with international prices. However, the lack of international benchmark prices for natural gas like those which exist for petroleum has led some regulatory bodies to establish base prices or initial prices for the sale of first-hand gas.

In all the countries studied, gas pipelines can be built and operated both by State enterprises and by private firms. In Argentina, Bolivia, Chile, Colombia and Peru there were already no restrictions on private participation in this area, and this situation was reaffirmed and expanded in the changes made to the legislation in the 1990s. The new development in this area was the elimination of the barriers which existed in Mexico to the participation of private operators in the transport, distribution and marketing of natural gas.

In almost all the countries studied, legal measures have been adopted to regulate the natural gas markets and the activities of private companies in the transport, distribution and marketing of gas, which has been given the status of a public service. 


\section{III}

\section{Forms of restructuring of the natural gas industry in Latin America}

In the countries studied, the ways in which the natural gas industry has been restructured are closely linked with the process of liberalization of markets and growing participation by the private sector, especially by the big international operators.

The local characteristics in terms of natural gas reserves, production and consumption have given rise to different domestic market structures in each country. There are also differences as regards expansion plans: whether these are based on expansion of the domestic market or on connections with other countries of the region. There is therefore no single restructuring model, although there is a general tendency towards liberalization in favour of private enterprise.

\section{Argentina: a country with a mature market}

Natural gas consumption is very widespread in Argentina, which has the biggest network of transport and distribution pipelines in the region $(50,000 \mathrm{~km})$. Natural gas is the second most important energy source for electric power generation in thermal plants after fuel oil, and it is expected that it will further increase its market penetration and replace large amounts of liquid fuels, resulting in better performance of thermal plants.

In 1992 and 1993 the State-owned enterprises YPF and Gas del Estado were privatized. With privatization of YPF, the whole of natural gas production is now in the hands of private firms, which can dispose of it as they wish. Three producers account for nearly $81 \%$ of the supply of gas in Argentina: YPF, Pérez Companc and Tecpetrol $(64,11$ and 6\%, respectively).

With the privatization of Gas del Estado in 1992 the transport and distribution of gas were separated. The privatization operation involved the sale of the two most important gas pipelines to different firms (Transportadora de Gas del Norte (TGN) and Transportadora de Gas del Sur (TGS)), which have a network of gas pipelines connecting the production centres with the various cities. In the mid-1990s these firms transported respectively some $65 \%$ and $35 \%$ of the natural gas produced in Argentina.

The privatization of the distribution networks of Gas del Estado involved their sale to eight different firms: Metrogas, Gas Natural BAN, Camuzzi Gas Pampeana, Camuzzi Gas del Sur, Litoral Gas, Centro, Cuyana, and Gasnor. The first three of these account for $54 \%$ of the gas distributed in the country.

The transport and distribution of natural gas are considered to be public service activities, so the State carries out important regulatory functions, through the National Gas Regulatory Body (ENARGAS), in such areas as the granting of concessions, access to transport and distribution networks, scales of charges, and consumer protection.

\section{Bolivia: priority given to the export of natural gas}

With reserves of some 110 billion $\mathrm{m}^{3}$, Bolivia occupies seventh place in Latin America. Natural gas is of great importance in primary energy production (58\% of the total), followed by oil $(24 \%)$ and hydropower and wood (6\% and 7\%).

Most of the natural gas produced is not consumed in the country but is exported to Argentina and Brazil; there is also a supply contract with Paraguay, but on a much smaller scale. Consequently, the share of natural gas in national primary energy supply amounts to only $25 \%$, compared with $42 \%$ for oil.

As a result of the entry of private capital into YPFB in 1996 and early 1997, private firms now control the whole of natural gas production under shared risk contracts with YPFB.

The new Hydrocarbons Law (No. 1689 of April 1996) lays down the forms of development of the natural gas industry, the characteristics of the regulatory body, and the mechanisms and forms of market regulation; it also regulates both export and domestic consumption, with a clear leaning in favour of exports. The Law lays down that producers must satisfy 
the demand for natural gas arising from the export commitments of the Bolivian State.

The construction of the Santa Cruz-São Paulo gas pipeline is one of the biggest projects undertaken by Bolivia in the last twenty years and provides for the supply of 105 billion $\mathrm{m}^{3}$ (3.7 million million cubic feet). The pipeline, which will be $3,700 \mathrm{~km}$ long, will involve investments of US\$ 2 billion. The agreement is for a period of 20 years; in the first eight years 8 million $\mathrm{m}^{3}$ of gas will be exported daily and in the following 12 years 16 million $\mathrm{m}^{3}$ per day, making a total of 93 billion $\mathrm{m} 3$ for the whole period.

There are also plans to build a gas pipeline to Paraguay. In September 1996 the two governments signed a contract for the export of 2.4 million $\mathrm{m}^{3}$ of natural gas per day, rising to 3.3 million $\mathrm{m}^{3}$ over a period of 10 years.

The idea is to make Bolivia the centre for the interconnection of natural gas integration projects. The domestic market will also be developed, as long as this does not conflict with regional energy integration.

\section{Colombia: towards more massive use of natural gas}

Colombia's natural gas reserves, at 214 billion $\mathrm{m}^{3}$, put it in fourth place among the countries of the region. Natural gas comes third among the primary energy products of Colombia, accounting for nearly $10 \%$ of the total; the shares of oil and coal are almost $49 \%$ and $26 \%$, respectively, followed by wood $(7 \%)$ and hydropower $(5 \%)$.

The natural gas produced $\left(7,674\right.$ million $\mathrm{m}^{3}$ in $1995)$ is used entirely for domestic consumption. Oil accounts for $43 \%$ of the total primary energy supply and natural gas for $13 \%$ (a similar proportion to those of coal (13.4\%) and wood (13.3\%). The natural gas producers have signed association contracts to supply gas at a fixed price to ECOPETROL, which is the enterprise that determines the forms of transport and distribution on the domestic market.

Since 1991, Colombia has been trying to increase domestic consumption of natural gas. To this end, it adopted a programme for the more massive use of gas, the main objective of which is to promote a more efficient energy consumption pattern through the replacement of high-cost energy products with gas. Specifically, the aim is to promote more massive use of propane gas by increasing the production and importation of this fuel; by optimizing the use of the available natural gas reserves through the construction of a nationwide transport network; by promoting private participation in the various investments called for by the plan, and by bringing gas prices level with the real costs of production and services.

The State oil company, ECOPETROL, is responsible for carrying out the programme for more massive use of natural gas. In 1992, the Ministry of Mining and Energy approved the general plan for the transport of natural gas, under which ECOPETROL is to develop the nationwide gas pipeline network. This network supplied 517,000 consumers in 1995, and it is hoped to reach a figure of 2 million in the year 2000, with total investments estimated at some US\$ 3 billion, plus the installation of thermo-electric plants to use natural gas, as scheduled in the 1995-2007 electric power expansion plan.

Colombia's natural gas strategy is based on the following division of tasks:

i) The gas transport system will be developed by ECOPETROL, either directly or through private investments under such systems as BOT (BuildOperate-Transfer) or the like, and through concessions granted by the Ministry of Mining and Energy.

ii) The construction and operation of the urban distribution networks will be the responsibility of private or mixed enterprises in which the departments or municipalities of the country may participate.

iii) A new body will be set up, with privatesector participation, to be responsible for running the gas transport and marketing system.

iv) A special regulatory system will be set up, together with independent legislation for the natural gas industry.

Colombia plans to secure a considerable increase in the domestic natural gas market, making use of the country's large reserves. ECOPETROL has an important role to play in this, as it will be responsible for building the gas pipelines and promoting private enterprise. The legislation for regulating the transport and distribution of natural gas is already in force.

\section{Chile: energy dependence and replacement of existing sources}

Chile's natural gas reserves amount to only 48 billion $\mathrm{m}^{3}$. Natural gas occupies second place in primary energy production, with $24 \%$ of the total, 
compared with the slightly more than $38 \%$ accounted for by wood. Hydropower accounts for $20 \%$, coal for $11 \%$ and oil for a little less than $7 \%$.

In order to satisfy its domestic energy needs, Chile has to import some 180,000 barrels of oil per day: this source covers $46 \%$ of the total primary energy supply, followed by wood and coal, with $19 \%$ and $15 \%$, respectively. Natural gas and hydropower account for $10 \%$ each.

Chile aims to increase domestic consumption of natural gas by importing gas from Argentina. In July 1995, the governments of Chile and Argentina signed a protocol liberalizing trade in natural gas, so that producers and consumers of the two countries will be completely free to negotiate volumes, transport, prices, places of origin and the terms of the corresponding commercial contracts. ${ }^{5}$

Development of the natural gas industry in Chile is entirely in the hands of private enterprise, and integration of gas supply with Argentina plays a crucial role in this process. The first gas pipeline to be built between Chile and Argentina was in Tierra del Fuego, built by a consortium made up of YPF and Bridas (Argentina) and Chauvco (Canada). ${ }^{6}$

Three gas pipelines have been built between Argentina and Chile in recent years. In August 1997 the gas pipeline belonging to GasAndes was inaugurated. GasAndes is a consortium made up of the Argentine firms Techint and Compañía General de Combustibles, Novacorp of Canada, and the Chilean firms Gasco and Chilegener. This pipeline, which supplies the Santiago market (the most important of the country), will bring about major changes in the energy balance of the country, since it will promote the construction of thermal electric power stations, thus favouring the sustainability of the energy supply process.

\footnotetext{
${ }^{5}$ Buyers and sellers will freely negotiate and contract the price of gas, the volumes involved, the necessary guarantees and other conditions usual in this type of contracts, as well as the facilities (including the necessary gas pipelines) for the transport of gas from the delivery points to the points of consumption.

${ }^{6}$ This gas supplies the plant belonging to Methanex Chile (a subsidiary of the Methanex Corporation of the Nova Group) at Punta Arenas in Southern Chile. This pipeline is $109 \mathrm{~km}$ long, but a further $106 \mathrm{~km}$ will be added between Poseidón and Cabo Negro to transport 2.9 million m3 per day as from 1999. Commercial deliveries began in January 1997 (see Latinominería, various issues).
}

In February 1997, a contract was signed between the Chilean firm ENDESA and the United States consortium CMS Energy for the construction of a gas pipeline between the Argentine province of Salta (Campo de Durán) and the province of Atacama in Northern Chile. The main objective of this project is to supply thermal power stations and mining companies in Northern Chile, where $30 \%$ of world copper production is located. It is calculated that the total investment will amount to US\$ 900 million.

The "Gasoducto del Pacífico" (Gas Sur) will link the gas reserves of Neuquén with the Bío-Bío area of Southern Chile. It will be $530 \mathrm{~km}$ long, and the total investment will be US\$ 400 million. The consortium led by Nova International (Canada), together with Gasco, YPF and El Paso Energy, will invest a further US\$ 44 million in natural gas services (transport and marketing), and in GasSur, a commercial and residential distribution system for the city of Concepción (Petroleum Economist, various issues).

\section{Mexico: private participation in transport and distribution}

In Mexico, primary energy consumption is marked by a clear predominance of oil, which accounts for $69 \%$ of the total (OLADE, 1996b). Natural gas accounts for $16 \%$ and associated and non-associated gas account for close to $3 \%$ of total consumption, while condensates account for $2 \%$. Thus, altogether hydrocarbons account for $90 \%$ of national primary energy consumption. The remaining $10 \%$ is made up of hydropower (3\%), wood (3\%), sugar cane bagasse $(1 \%)$ and other types of energy (1\%).

The most important items in natural gas consumption are extraction of liquefiable components, consumption by the gas sector itself, use of gas for energy generation, and final non-energy forms of consumption. Another important area is that of industrial consumption, where the demand of the petrochemical industry is outstanding. Natural gas has not managed to penetrate the residential sector, and its use in transport is zero.

All exports and imports of natural gas by Mexico are to or from the United States.

Natural gas production continues to be a State monopoly of PEMEX, since no change took place in this situation in the 1990s. Important changes have been made, however, with regard to the transport and marketing of natural gas. In 1995 the Mexican Congress adopted the Law Regulating Article 27 of the 
Constitution which allows the transport, storage and distribution of natural gas to be carried out (subject to the approval of the Federal Electricity Commission (FCE)) by the social and private sectors, which can build, operate and own pipelines, installations and equipment under the terms of the legal, technical and regulatory conditions laid down by the Law. This measure was supplemented with the assignment of new functions and powers to the Energy Regulation Commission and the adoption of the Natural Gas Regulations in November 1995.

These changes in the legislation are indicative of the boost that the Government seeks to give to the domestic consumption of natural gas, which still only accounts for $4 \%$ of residential energy consumption and has not penetrated into the field of transport at all. There would therefore appear to be solid grounds for expecting an increase in domestic demand in the future.

The reforms do not extend to aspects connected with the production of natural gas, which continues to be the sole responsibility of PEMEX. However, private firms will now be able to build and own new gas pipelines additional to the $12,000 \mathrm{~km}$ of trunk pipelines owned by PEMEX. The private firms will have free access to the PEMEX network, while PEMEX, for its part, will have free access to the privately-owned pipelines. PEMEX considers that these and other projects could give rise to some US\$ 4 billion of private investments in the next few years.

This new policy puts an end to the State monopoly of the transport and distribution of natural gas in Mexico. Presumably, PEMEX will not participate in the construction of new gas pipelines except in special cases connected with the production of both oil and gas.

\section{Peru: predominant role of private enterprise and development of the domestic market}

Peru's natural gas reserves amount to 201 billion $\mathrm{m}^{3}$, corresponding to the fifth place in Latin America as a whole. Most of the reserves are in the Camisea area, near Cuzco, and are still to be brought into production. It is estimated that the Camisea reserves of natural gas and condensates could amount to 340 billion $\mathrm{m}^{3}$ (12 million million cubic feet) and 650 million barrels, respectively.

Natural gas does not currently occupy an important place in the primary energy production of Peru, accounting for a little less than $2 \%$ of the total. The main energy source is oil, with a share of $50 \%$, followed by wood with $31 \%$ and hydropower with $12 \%$; the remainder is accounted for by products derived from sugar cane and other sources.

Natural gas production is as yet very small: some 258 million $\mathrm{m}^{3}$ in the mid-1990s. ${ }^{7}$ Its share of total primary energy supply is only $1.4 \%$, compared with $53 \%$ for oil and $28 \%$ and $11 \%$ respectively for wood and hydropower.

Exploitation of the Camisea gas deposits is a key element in Peru's energy policy, since it will make it possible to increase the reserves of natural gas and condensates, promote conversion to cleaner fuels, and generate foreign exchange through probable exports.

In May 1996 a 40-year contract was signed with the Shell-Mobil consortium for the exploitation of the Camisea deposits. The three stages of the contract provide for total investments of US\$ 2.4 billion; the State would not participate in these investments and would leave the execution of the works in the hands of the consortium.

In mid-July 1998, at the end of the first stage and after arduous negotiations between the parties, the Shell-Mobil consortium decided not to continue with the second stage, so that the contract was terminated. The consortium considered that under the prevailing conditions the Camisea project would only give a yield of $8.4 \%$ on the investments in the project, which was not considered to be acceptable as it would not allow the investments to be recovered in the desired space of time.

In order to continue with the second stage, the consortium demanded a number of new incentives, such as acceptance by the government of a higher price for the natural gas than that laid down in the contract, participation in gas distribution in Lima, the possibility of exporting gas to Brazil through a connection with the Santa Cruz-São Paulo gas pipeline, and reforms in Peru's electricity legislation to guarantee a price for natural gas which would allow it to compete with other fuels for supplying thermal power stations. In August 1998 a High-Level Commission was set up to organize international bidding

\footnotetext{
${ }^{7}$ Most of the gas produced is used by the petroleum industry itself, though it also supplies the city of Talara in northern Peru.
} 
for the development of this resource, expected to take place in September 1999.

In 1998 natural gas production began in the Aguaytía deposits. The investments made will permit the production of 6,314 million $\mathrm{m}^{3}$ (223 billion cubic feet). It is estimated that annual production will amount to 569 million $\mathrm{m}^{3}\left(1.58\right.$ million $\mathrm{m}^{3}$ per day) and that 4,000 barrels of liquefied petroleum gas (LPG) will also be obtained. The gas produced will be used to operate two thermal power stations: one for the city of Pucallpa and the other at Aguaytía. The latter, which will have a capacity of $140 \mathrm{MW}$, will be linked up with the Centre-North electricity grid.
At the time of writing this article, there was no regulatory framework for the natural gas industry as regards the production, transport, distribution and marketing of gas. In December 1996 Law No. 26734 was adopted, which set up the Supervisory Body for Investments in Energy (OSINERG), to be responsible for monitoring compliance with the legal and technical requirements regarding the activities of the electricity and hydrocarbons sectors and the rules on conservation and protection of the environment. Its powers do not extend to the fixing of charges for the transport and distribution of gas or to the granting of concessions, however.

\section{IV}

\section{The boom in natural gas investments, and regional energy integration}

In Latin America, natural gas has been used above all in industry, and especially in the petrochemicals industry, except in Argentina, where it has for many years been used on a large scale for commercial and residential purposes. Natural gas was not used to generate electric power, because hydropower was predominantly used for this purpose, while the thermal power stations used fuel oil or coal.

In recent years, however, there has been a significant increase in the demand for natural gas for electricity generation. It is estimated that the countries of the region will require over $90 \mathrm{GW}$ of extra power in the period from 1995 to 2005 , and a further $24 \mathrm{GW}$ in the period from 2005 to 2010, mainly supplied by the private sector (Kurtz, 1997). This demand could be satisfied with thermal power stations using natural gas, particularly as the possibilities of developing hydroelectric projects are likely to be very limited. ${ }^{8}$ It is also expected that the construction of thermal power stations using natural gas will held to reduce electric-

\footnotetext{
${ }^{8}$ One of the most important uses for natural gas all over the world will be closely linked with electric power generation. It is calculated that world investments in electric power generation will amount to US\$2.28 million million over the period from 1995 to 2010, two-thirds of which will be made in developing countries. In Latin America, the total expected investment in electric power projects over the same period is US\$ 203 billion, of which US\$23 billion will correspond to thermal power stations using natural gas (United States Department of Energy, 1998).
}

ity prices, as this fuel is cheaper than the fuel oil used in the thermal power stations that usually serve the market at peak hours.

The preference for natural gas is due, among other things, to the high cost of hydroelectric power generation works; to the new policies of multilateral development agencies (the World Bank and the Inter-American Development Bank), which involve the virtual termination of finance for hydroelectric projects; to technological innovations in combinedcycle thermal power stations, which are quicker to build and cost less than hydroelectric power stations; to improvements in the systems of transport and distribution of natural gas, and to the lower environmental pollution caused by natural gas compared with coal and fuel oil.

National plans for increasing the use of natural gas coincide with various initiatives designed to promote greater regional energy integration, such as the considerable increase in the number of gas pipelines linking producer and consumer countries.

The natural gas investment projects identified in the region amount to over US\$29 billion (table 2). They mostly concern investments in international or domestic gas pipelines. This figure does not include investments in related projects, such as the construction of thermal power stations or the development of petrochemical complexes (except for the petrochemical projects in Argentina and Trinidad and Tobago). 
TABLE 2

Latin America: Natural gas projects

(Millions of dollars)

\begin{tabular}{|c|c|c|c|c|}
\hline Projects & Countries & $\begin{array}{c}\text { Total } \\
\text { investment }\end{array}$ & Length & Status \\
\hline \multicolumn{5}{|l|}{ Regional integration projects } \\
\hline GasAndes ${ }^{\text {a }}$ & Argentina-Chile & 350 & $450 \mathrm{~km}$ & Executed \\
\hline Atacama ${ }^{b}$ & Argentina-Chile & 900 & 914 & Underway \\
\hline GasSur $^{c}$ & Argentina-Chile & 400 & 530 & Underway \\
\hline Tierra del Fuego-Cabo Negro & Argentina-Chile & 70 & & 1999 \\
\hline Gaucho d & Argentina-Chile & 200 & 440 & Underway \\
\hline Buenos Aires-Montevideo & Argentina-Paraguay & 135 & 200 & Underway \\
\hline Mega $^{e}$ & Argentina & 500 & 600 & Underway \\
\hline Mercosur & Argentina-Bolivia-Brazil & 3100 & 1500 & Feasibility study \\
\hline Santa Cruz-São Paulo & Bolivia-Brazil & 2000 & 1350 & Underway \\
\hline Bolivia-Paraguay & Bolivia-Paraguay & 300 & 1000 & Feasibility study \\
\hline Subtotal & & 7955 & & \\
\hline \multicolumn{5}{|l|}{ National projects } \\
\hline Petroquímica Bahía Blanca & Argentina & 700 & & Underway \\
\hline Polisur & Argentina & 250 & & Underway \\
\hline Plan to promote massive use of natural gas & Colombia & 3000 & & Underway \\
\hline Natural gas distribution & Mexico & 4000 & & Underway \\
\hline Camisea & Peru & 2500 & & Feasibility study \\
\hline Aguaytía & Peru & 250 & 215 & Executed \\
\hline Trinidad and Tobago & Trinidad and Tobago & 5000 & & \\
\hline Cristóbal Colón Project & Venezuela & 5500 & & Feasibility study \\
\hline Subtotal & & 21200 & & \\
\hline Total & & 29155 & & \\
\hline
\end{tabular}

Source: Prepared by the author on the basis of research results.

${ }^{a}$ Mendoza-Santiago. $\quad{ }^{b}$ Salta-Atacama-Mejillones. ${ }^{c}$ Neuquén-BíoBío.

${ }^{\mathrm{d}}$ Entre Ríos-Uruguayana-Porto Alegre. $\quad{ }^{\mathrm{e}}$ Neuquén-Bahía Blanca. Includes exports to Brazil.

\section{V}

\section{Regulatory arrangements for the natural gas industry in Latin America}

\section{Principles and objectives of regulation}

At the time of writing of this report, only Argentina, Bolivia, Chile, Colombia and Mexico had laws governing the natural gas transport and distribution markets. In Peru and Venezuela, the corresponding legislation has not yet been officially adopted. ${ }^{9}$

${ }^{9}$ This section of the article is based on the legal instruments and publications of the various bodies and ministries of the countries studied. The complete list may be found in Campodónico, 1998.
The main principles of legislation on the gas industry are similar in almost all the countries studied. The idea is to give due protection to end-users, bearing in mind the fact that some phases of the gas industry (transport and distribution) represent natural monopolies. In these cases, the State has to intervene to ensure free competition, to prevent possible abuse of dominant market positions, and to promote the continuity and quality of the services provided. When these cannot be provided under conditions of competition, the State has to intervene to ensure that the operations are efficient, which means optimizing the quality-price ratio. 
The programmes of action of the regulatory bodies are based on the basic principles of gas industry regulation, which include inter alia: fair or reasonable profits; competition; efficiency and rationality; optimization of quality; reliability, safety and continuity of the service provided; access without discrimination, and maximum coverage. With respect to these principles, the regulatory frameworks include such objectives as:

- Promoting the interests and rights of users through improvement of the quality of public service and ensuring that its ultimate purpose is to provide users with a better quality of life;

- Promoting competition in the natural gas supply and demand markets in order to avoid abuses due to a dominant market position;

- Promoting better operation, reliability, equality, free access, non-discrimination and generalized use of natural gas transport and distribution services and installations;

- Regulating natural gas transport and distribution and ensuring that the prices charged are fair and reasonable;

- Ensuring the continual and uninterrupted provision of services at all times, except when there are reasons of force majeure, acts of God, or technical or economic reasons which prevent this;

- Raising the levels of safety and reducing the number of incidents connected with the provision of service;

- Promoting the rational use of natural gas while ensuring due protection of the environment;

- Promoting investments to ensure supplies in the long term.

The various types of national legislation do not deal explicitly with matters of social equity and user participation, except in Colombia, where the legislation lays down that coverage must be constantly expanded, with arrangements to compensate for insufficient payment capacity of users, and users must be guaranteed adequate access to the services and participation in their management and control.

\section{Natural gas supply as a public service}

All the countries studied make a distinction between the production and the transport and distribution phases. The production of natural gas is considered to be a matter of general interest, governed by the conventional standards of the market and competition, so it is not subject to regulation. In concrete terms, this means that the wellhead price of natural gas -also known as the "first-hand" price- is determined by the laws of supply and demand.

The transport and distribution of natural gas, in contrast, are considered to be public service activities, so that they are subject to State regulation.

\section{Establishment of regulatory bodies}

In all the countries which have regulatory frameworks, regulatory bodies have been set up which have varying forms depending on the way the Executive is organized. They are generally administratively autonomous, however. In some cases they come under ministries (Argentina, Colombia), in others they form part of the national regulatory systems (Bolivia), while in Chile regulation is carried out by an inter-ministerial commission. They also vary in their forms of financing. In some cases they depend on the general budget, but in others (Bolivia and Colombia) they are financed with contributions from the companies they regulate.

In Argentina, the National Gas Regulatory Body (ENARGAS) was set up under the Ministry of the Economy and Public Works and Services. In Bolivia, there is a Superintendency of Hydrocarbons belonging to the Sectoral Regulation System (SIRESE), which is part of the Executive, under the supervision of the Ministry of Finance and Economic Development. In Colombia, the legal figure of "Public Service Companies" exists and has its own legislation. The Regulatory Commission for Energy and Gas Fuels acts in the sector as a special administrative unit of the Ministry of Mining and Energy, with administrative, technical and financial autonomy.There is also the Superintendency of Household Public Services, which is responsible, at the behest of the Office of the President of the Republic, for the control, inspection and supervision of the bodies providing such services. Chile has no specialized regulatory body for the natural gas industry. The National Energy Commission, under the direction of the Ministerial-level President of the Commission, is responsible for regulation, while the Superintendency of Electricity and Fuels, which comes under the Ministry of the Economy, carries out routine supervisory functions. In Mexico, the Energy Regulation Commission (CRE) is responsible for regulation of the gas sector; it is a quasi-autonomous body coming under the Ministry of Energy, which in turn comes under the Executive. 
The functions of the regulatory bodies are similar in almost all the countries studied, namely:

- To grant concessions and licences to firms transporting and distributing natural gas and to cancel or revoke them when necessary;

- To supervise fulfilment of the obligations and rights of concessionaires and licensees;

- To protect the rights of consumers, concessionaires and producers;

- To ensure compliance with the legislation designed to prevent monopolies and protect competition;

- To guarantee free and non-discriminatory access to pipelines;

- To regulate, fix scales of charges, and promote the efficiency and continuity of transport and distribution services;

- To carry out all inherent and necessary actions for the fulfilment of their functions in accordance with the prevailing rules.

The regulatory bodies may also have special characteristics and powers, however. In Chile, the scales of charges for transport and distribution are freely determined and are not subject to regulation, except in the case of users with a consumption of less than 100 gigajoules. In Mexico, the body responsible for fixing transport and distribution charges is the Committee on Petroleum, Natural Gas and Petrochemical Products, which is made up of representatives of a number of bodies, including the Ministry of Energy.

\section{Prohibition of vertical integration}

The question of vertical integration has been a source of concern to regulators. Depending on the type of activity and the size of the markets to be regulated, it is often considered that vertical integration could give rise to situations which might affect competition.

In the region, only in Chile are there no express prohibitions that regulate the natural gas industry. Vertical integration between the activities of production, transport and distribution is only explicitly and categorically forbidden in Argentina and Colombia; in Bolivia and Mexico it is partially prohibited, with some exceptions.

The Bolivian legislation authorizes vertical integration for projects and operations in isolated areas which would not be financed or be economically profitable without it, or when it is necessary for the development of new domestic piped natural gas dis- tribution networks, whose efficiency depends on vertical integration.

In Mexico, the Energy Regulation Commission (CRE) can authorize vertical integration when it considers that this will give benefits in terms of greater efficiency and profitability of the service or when it is absolutely necessary because the transport infrastructure needed for developing the market in a given geographic area does not exist and there are no other firms interested in undertaking the transport or distribution project.

\section{Free access to transport and distribution networks}

In Argentina, Bolivia, Chile, Colombia and Mexico the law lays down that concessionaires or licensees must give users free access to the services offered by their systems, without any kind of discrimination. The legislation in force does include some limitations on such freedom of access, however, connected with the available or non-contracted capacity and the effective use of capacity contracted. It stipulates that in any case the potential user must sign the corresponding contract for the provision of the services in question.

In Colombia, there are codes on transport and distribution which provide mechanisms whereby producers, marketers, major consumers and distributors can put into effect the principle of free access to the networks.

\section{Establishment of wellhead prices}

In most of the countries studied the wellhead price of natural gas is considered to be a matter of general interest and is therefore not subject to regulation. There are problems in determining the price of the gas, however, since unlike oil there is no international posted price for natural gas. In some cases, the international price of fuel oil is used as a benchmark, as this fuel can be replaced with natural gas. It could happen that as the gas reserves increase and the possibility of gas taking the place of other fuels increases, its opportunity cost may be more closely linked with the average costs of producing, transporting and distributing gas.

In Argentina, the wellhead price of natural gas is a matter of general interest, since it is the result of the free play of supply and demand, while in Bolivia, where most of the gas produced is exported to Ar- 
gentina, the price is determined in negotiations between the two countries. The same will occur in the case of Bolivia's future exports to Brazil through the Santa Cruz-São Paulo gas pipeline. ${ }^{10}$

In Colombia, the law lays down that there will be freedom of prices when there is effective competition between suppliers and there is no domination of the market, to be determined by the regulatory body. In the transitional period, even though various forms of price fixing may be applied, ECOPETROL buys natural gas from its associates at a price corresponding to the international price of fuel oil. ${ }^{11}$

In Chile, prices are determined freely by exporters and importers in accordance with the terms of the 1995 economic complementation agreement between Argentina and Chile.

In Mexico, the prices of dry gas are the same as those in effect in South Texas (because of the possibility of access to that market), plus transport and service costs and the value added tax. For fixing domestic prices, the domestic fuel prices index (linked to a basket of prices on the United States market) is applied, plus transport costs in line with the import parity system.

In Peru, the authorities have not yet legislated on these matters. In oil and natural gas contracts, the form of valuation is determined in each individual case, but generally speaking the market price is used. Thus, for example, the contract with the Shell/Mobil consortium for exploitation of the Camisea gas deposits, which was signed in May 1996, lays down that the value of the natural gas will be calculated ac-

\footnotetext{
${ }^{10}$ In 1995, the average wellhead price in Argentina was US\$ 1.125 per million British Thermal Units (BTUs), which is equivalent to US\$ 1.20 per thousand cubic feet. The price of the gas to be exported from Bolivia to Brazil will be US\$ 0.90 per thousand cubic feet. For new contracts, or when the existing contracts expire (in five years' time), the price for sales to thermal power stations, industrial plants and distributors of piped gas will be calculated as follows: First, the weighted wellhead price for exports to Argentina and Brazil will be determined, and this price will be increased by the cost of transport for domestic use. This amount will be multiplied by a factor of 1.1494 , and the result will be the price charged to producers and consigners at the point of delivery on the domestic market.

${ }^{11}$ As long as prices are not free, the maximum initial price at the entry node into the national transport system will be US\$ 1.30 per million BTUs (US\$ 1.391 per thousand cubic feet). This price will be reviewed every six months as from 1 January 1996, on the basis of a formula taking into account the variation in the price index for standard crude quoted on the New York Mercantile Exchange (NYMEX).
}

cording to the effective price, which must reflect the market price of the gas produced in the contract area. The effective price is defined as the price effectively paid by the purchaser to the natural gas contractor, in this case the Shell/Mobil consortium. ${ }^{12}$

In Venezuela, the prices reflect the opportunity cost and vary according to the geographical location. ${ }^{13}$ By way of reference, it may be noted that in the United States gas prices are free and register considerable fluctuations according to the season of the year. ${ }^{14}$

\section{Regulation of transport and distribution charges}

In Argentina, Bolivia, Colombia and Mexico, the regulatory bodies fix the natural gas transport and distribution charges, but in Chile they only regulate the charges made to users of less than 100 gigajoules. In the countries which do regulate charges, the price paid by the final user is the result of the natural gas price negotiated in the wholesale market, plus transport and distribution charges. There are various different ways of calculating the transport and distribution charges, however.

In Argentina, ENARGAS approves proposed charges and sets a maximum or ceiling charge, adjustable by a price index and a productivity factor. As these are maximum charges, the service supplier can reduce them in the light of his commercial interests (to maintain or expand markets) without any need for ENARGAS's approval, provided of course that they cover his costs.

ENARGAS must ensure that transporters and distributors who operate properly will earn enough to cover all reasonable operating costs involved in the provision of their services, taxes, amortization costs and a reasonable profit margin. The concept of rea-

\footnotetext{
12 In the Reference Plan for the Electricity Sector the Ministry of Energy and Mining makes a forecast of the prices for natural gas from Camisea as well as from Aguaytía and Talara. These prices are US\$ 1.5 per thousand cubic feet at the Camisea wellhead and US\$2.5 delivered in Lima; US\$2.5 at Aguaytía, and US\$2.0 at Talara.

${ }^{13}$ It is estimated that the price will be US\$ 0.53 per thousand cubic feet at José and US\$ 0.642 at Puerto Ordaz (OLADE, 1997b).

${ }^{14}$ Wellhead prices in the United States were US\$ 1.59 per thousand cubic feet on average in August 1996 (Oil \& Gas Journal, various issues).
} 
sonable profits is defined, in current Argentine law, as those which could be obtained in other activities of comparable risk, and it must also be in line with a reasonable level of efficiency and satisfactory quality of the services provided.

The charges fixed by ENARGAS must take into account the possible differences that could exist between the different types of services as regards the form in which they are provided, geographical location, relative distance from the gas deposits, and any other aspect that it considers to be relevant. Although the sale price by the distributor to the consumer includes the acquisition and other costs involved in providing the service, it is the responsibility of the regulatory body to ensure that consumers are charged the lowest prices compatible with security of supply.

In Mexico, the system adopted is also that of a ceiling tariff, proposed to the Energy Regulation Commission by the firms wishing to provide the service. The initial tariffs authorized must be such as to allow them to make rational use of the resources and, if adjusted, to ensure them sufficient income to cover reasonable costs of operating and maintaining the service, taxes, depreciation and a reasonable return on capital. This mechanism does not, therefore, necessarily guarantee the income, costs or returns expected by those applying for permission to provide the service.

The method of fixing tariffs is not applicable when the Energy Regulation Commission considers that there is effective competition in the market. The concessionaires are therefore entitled to request the regulatory body to issue a ruling on whether such competition effectively exists.

In Bolivia, regulation is through the rates of return. The tariffs for transport of hydrocarbons and their products by pipelines and for the distribution of natural gas through piping systems must be approved by the Superintendency for Hydrocarbons, which is a department of the Sectoral Regulation System.

The mechanism adopted is such that it guarantees a certain rate of return on the investments made by the concessionaires. In this respect, the regulatory body must ensure that users of the pipeline transport system and the local natural gas distribution systems pay the lowest possible costs compatible with the security and continuity of the service. Such costs must ensure that the concessionaires, with rational and prudent management, will receive sufficient in- come to cover all their operating expenses, taxes (except for taxes on remittances of profits abroad), depreciation, and financial costs and to give a reasonable rate of return on their net worth. The regulatory body should therefore incentivate concessionaires to increase the efficiency of their operations.

In Colombia there is no single tariff system. If the market is not dominated by a single firm and there is therefore a situation of competition (a situation which must be officially attested by the regulatory body), public service companies in the gas sector can fix their tariffs freely. If not, they are subject to a regulatory system providing for two forms of operation: monitored freedom and regulated freedom. The first of these applies when there is competition and the second when the market conditions call for intervention by the regulatory body.

The companies are subject to price fixing formulas periodically determined by the regulatory body. On the basis of a cost study, the regulatory body can set compulsory maximum and minimum tariffs and decide when the monitored and regulated forms of operation should be applied.

The methods based on a maximum tariff (including also a minimum rate) and a given rate of return on the investment operate in combination.

The law lays down that the methods used in fixing the tariffs must be guided by considerations of economic efficiency, neutrality, solidarity, redistribution, financial soundness, simplicity and transparency, with priority being given to criteria of economic efficiency and financial soundness when fixing tariffs. If conflicts arise between the two criteria, the tariffs must be defined on the basis of financial soundness, which, in the opinion of the regulatory body, will ensure economic efficiency.

The aim of the system is that the tariffs should be close to those that would apply in a competitive market. To this end, the tariff-fixing formulas must take into account not only costs but also expected increases in productivity, the benefits of which must be shared between the concessionaires and their users, as would occur in a competitive market. Thus, the tariff-fixing formulas cannot pass on the costs of inefficient management to users nor allow the concessionaires to appropriate profits deriving from practices that restrict competition.

In public services the tariff formulas must always reflect the level and structure of the economic costs of providing the service, and also the demand. 
All consumers are entitled to the same treatment in terms of tariffs if they cause the same costs to the service companies. However, this right must not prevent the service companies from offering various tariff options or the consumers from choosing the option that suits them best.

When the tariff system is put into practice measures will be taken to allocate resources to solidarity and redistribution funds so that users in the upper strata and commercial and industrial users will help low-income users to pay the cost of the services needed to cover their basic needs.

The tariff formulas must ensure that concessionaires recover their operating costs and expenses, including those of expansion, replacement and maintenance, and are able to give their shareholders returns on their investments comparable with those of an efficient firm in a sector with the same level of risk (the rate-of-return method). Technologies and management systems which ensure the highest quality, continuity and security of the services will be used for this purpose.

The tariff fixing formulas will be prepared in such a way as to facilitate their understanding, application and control.

The tariff system itself will be explicit and completely public for all the parties involved in the services and also for users.

\section{Cross-subsidies and fiscal subsidies}

The policies applied in the countries studied differ with regard to subsidies. There are two main tendencies among the countries of the region.

In Argentina, Bolivia, Chile and Mexico, crosssubsidies are prohibited but fiscal subsidies may be granted. In Argentina, cross-subsidies are prohibited but fiscal or government subsidies may be granted provided that they are explicitly provided for in the national budget. They may be granted to residential users in Southern Argentina and to various types of pensioners.

In Bolivia, cross-subsidies are prohibited but it is not clear from the legislation whether fiscal subsidies may be granted. Cross-subsidies are not permitted in Chile, either, but in the case of users consuming less than 100 gigajoules the tariffs may be regulated if it is shown that the tariff system makes possible operating revenues that represent a rate of return more than $5 \%$ higher than the annual capital cost rate.

Cross-subsidies are not permitted in Mexico. Fiscal subsidies provided through the tariffs can only be granted under decisions taken by the competent authorities and must be covered by resources officially allocated for the purpose. They must not affect the income of the concessionaires nor represent an extra cost for them. They must be granted in a transparent manner and must be explicitly shown in the tariffs charged to users.

In Colombia, cross-subsidies are permitted for the purpose of assisting low-income sectors. Public service companies which provide or market gas fuels will collect them, on behalf of the consumers they supply, by contributing to the National Solidarity and Income Redistribution Fund an amount resulting from the application of a factor of $20 \%$ to the city-gate cost of the gas supply, as stipulated by the Domestic Energy and Gas Regulatory Commission. The resources obtained by that Fund will be used to provide subsidies for low-income users, as a social investment under the conditions established by the law. The Solidarity and Income Redistribution Funds set up by the local municipal councils receive transfers from the public service companies and grant the subsidies as laid down by the law.

The legislation of the countries studied does not contain any references to the system of taxation to be applied, so it may be inferred that companies operating in the natural gas industry will be subject to the normal tax system. 


\section{VI}

\section{Conclusions}

The increase in production and consumption of natural gas all over the world, but especially in the developing countries (China, Southeast Asia and Latin America) is a feature of the energy markets and will tend to grow even stronger in the medium and long term for various reasons: technological progress, geographical dispersion of gas deposits, less environmental pollution than other fossil fuels, growth of the energy markets in the emerging countries, and considerations relating to the geographical security of supply, especially in the case of the industrialized countries.

The changes made in hydrocarbons legislation in the 1990s in the countries of the region have been aimed at opening up and deregulating markets in order to attract new investments. The abundant natural gas reserves in a number of these countries give grounds for expecting that investments in the coming years will amount to the impressive figure of US\$ 29 billion.

The high cost of exporting natural gas by sea has caused the use of this fuel to be aimed at meeting the energy needs of the domestic markets of the countries of the region (thermal power stations, industrial and domestic use, development of the petrochemicals industry) and at promoting regional energy integration by building cross-border gas pipelines.

In almost all the countries studied, the production of natural gas is in the hands of various public and private oil companies and its price is not regulated but is subject to the law of supply and demand. In many countries, however, the State intervenes to fix wellhead prices because this is a very new industry and there is no single international price to serve as a benchmark for all markets.

In the supply of natural gas and electricity to end-users the price is not fixed by supply and demand but is regulated by the State. This is because the transport and distribution of natural gas are based on pipeline systems which form a natural monopoly and because this is an energy source which is considered to be a public service. These two aspects make State regulation necessary in order to ensure free competition in gas supply (it may be recalled that, before the reforms, in almost all countries of the region the provision of public services was reserved for the State), to prevent possible abuses by those enjoying a dominant market position, and to favour the continuity and quality of the services provided. It is considered that when a situation of competition does not exist, the State must step in to ensure that operations are efficient, which means optimizing the quality/price ratio.

The new legislation on regulation in the countries of the region gives monopoly rights and other special rights to electricity and gas companies, within the context of their public service obligations. The degree and form of regulation vary considerably, depending on the ownership of the company, the sources of power generation, the administrative traditions of the countries concerned, and also political considerations.

In the 1990s there was a general tendency towards the existence of regulatory bodies in almost all the countries of the region; in some cases these bodies are only two or three years old, which means that they are still at the learning stage. It is therefore extremely important that governments should promote training policies and give the work of these bodies the necessary support.

Some of the key areas for action by governments and regulatory bodies could include the following:

- Control of the use made of natural resources, especially oil and natural gas.

- Regulation of the pipeline industries, with growing emphasis on the promotion of competition; ensuring free access to the pipeline systems; a flexible approach to the vertical integration of transport and distribution, with special emphasis on strict regulation; transparency and equity in the fixing of natural gas transport and distribution tariffs; and protection of consumers' rights.

- Dissemination of information and greater education of energy users.

- Intervention in large-scale contracts for natural gas imports.

- Strengthening of environmental regulations regarding energy production and use, including study 
of the viability of using tax policy as an active instrument in energy and environment policies.

- Technological research and development.
- Promotion and increased use of renewable energy sources.

(Original: Spanish)

\section{Bibliography}

Campodónico, H. (1996): El ajuste petrolero: políticas empresariales en América Latina de cara al 2000, Lima, Ediciones DESCO.

-(1998): La industria del gas natural y las modalidades de regulación en América Latina, "Medio ambiente y desarrollo" series, No. 9, Santiago, Chile, Economic Commission for Latin America and the Caribbean (ECLAC), Environment and Development Division.

Kurtz, D. (1997): Natural Gas in Latin America: Development and Privatization, London, Financial Times Energy Publishing.

Latin Finance (various issues): Miami, Florida.

Latinominería (various issues): Santiago, Chile, G\&T International.

OECD (Organization for Economic Cooperation and Development), International Energy Agency (1995): World Energy Outlook 1995, Paris.

Oil and Gas Journal (various issues): Oklahoma, Penn Well Publishing Company.
OLADE (Latin American Energy Organization) (1996a): Alternativas de integración en el mercado latinoamericano y caribeño del gas natural: estudios de casos, Quito, November.

- (1996b): Alternativas de integración en el mercado latinoamericano y caribeño del gas natural: el caso de México, Quito, November.

- (1997a): Sistemas de información económica energética, Quito.

-(1997b): Modernización, desincorporación de activos y libre comercio en la actividad de gas natural en América Latina y el Caribe, Quito, April.

Peru, Ministerio de Energía y Minas (1997): Plan referencial de electricidad, Dirección General de Electricidad, Lima.

Petroleum Economist (various issues): London, Sedgwick Energy Limited.

United States, Department of Energy (1995): International Energy Outlook 1995, Washington, D. C.

-(1998): International Energy Outlook 1998, Washington, D. C 